\title{
Latina Super-heroines: Hot Tamales in Tights vs. Women Warriors, Wrestlers and Guerrilla Fighters of La Raza
}

\author{
Carolina FERNÁNDEZ RODRÍGUEZ \\ Universidad de Oviedo \\ Departamento de Anglogermánica y Francesa \\ carol@uniovi.es
}

\begin{abstract}
The year 1977 saw the making of the first Latino superhero by a Latino artist. From the 1980s onwards it is also possible to find Latina super-heroines, whose number and complexity has kept increasing ever since. Yet, the representations of spandexed Latinas are still few. For that reason, the goal of this paper is, firstly, to gather a great number of Latina super-heroines and, secondly, to analyze the role that they have played in the history of American literature and art. More specifically, it aims at comparing the spandexed Latinas created by non-Latino/a artists and mainstream comic enterprises with the Latina super-heroines devised by Latino/a artists. The conclusion is that whereas the former tend to conceive heroines within the constraints of the logic of Girl Power, the latter choose to imbue their works with a more daring political content and to align their heroines with the ideologies of Feminism and Postcolonialism.
\end{abstract}

Keywords: Latina super-heroines, Girl Power, feminist empowerment, sexism, racism.

\section{LATINO/A SUPERHEROES: A BRIEF HISTORY}

Comic books appeared in the US in the 1890s, and their mainstream variety enjoyed a golden age between the 1930s and the 1950s. In the 1970s underground comics acquired more and more notoriety; so much so, that in the 1980s and 1990s, under the influence of those alternative comics, Marvel and DC started to create characters with greater psychological complexity and to offer stories where racial, gender, ethnic and sexual concerns were progressively dealt with.

As the superhero comic has traditionally been a favorite, the first Latino characters that ever populated mainstream comics have actually been Latino superheroes. For example, Marvel's first Latino superhero, Hector Ayala, the White Tiger, appeared in 1975 in Deadly Hands of Kung-Fu (issue 19; by Bill Mantlo and George Perez); in 1979 there appeared Marvel's Alejandro Montoya, el Águila, a criollo urban crime fighter (Power Man and Iron Fist, issue 58). Finally, in 1981, Marvel allowed its first Latina superhero, Bonita Juarez, Firebird, to see the light in the pages of The Incredible Hulk (volume 2, issue 265; by Bill Mantlo and Sal Buscema). DC, for its 
part, introduced its first Latino superhero, El Dorado, in the 1970s in Justice League of America (by Gerry Conway and Chuck Patton).

Although the first Latinos tended to be rather stereotypical (El Dorado speaks a heavily accented Spanglish and carries an Aztec solar calendar on his chest; Bonita Juarez is a devout Catholic and Montoya an impetuous and reckless person), as time went by both Marvel and DC started to offer more complex characters ${ }^{1}$ : they do not necessarily have any particular accents but can comfortably code-switch from English into Spanish and the other way round; some of them are of mixed-race, as for instance Marvel's green-eyed Anna (X-Force, issue 117, by Peter Milligan and Mike Allred, 2001), an Irish and Latina superhero; occasionally, they even become the protagonists of best-selling comics, as did Jaime Reyes, Blue Beetle, in Infinite Crisis (issue 3, 2006, by Geoff Johns and Phil Jiminez), a comic series commended for its success in portraying the complexity of Latino identity and experience (Aldama 2009: 41).

In part, at least, that greater depth in the representation of Latinos/as may be caused by the fact that in recent times mainstream comics are sometimes employing Latino comic artists, as for example Joe Quesada, a Cuban-American author-artist and Marvel's editor in chief, who is responsible for introducing the Santerians, a Latino superhero team, in Daredevil: Father (issue 2, 2005). But Latino artists had been creating superhero comics from the late 1970s, even if their works did not make it to the mainstream companies until much later. Thus, in 1977 Texas Judge Margarito C. Garza is said to have created the first Latino superhero, Marcos Zapata, in Relampago. For a few years after that, Latinos stopped creating more Latino superheroes, until in the 1990s there appeared a large number of artists who contributed to the birth of further Latino characters with superpowers. Let two names suffice $^{2}$ : first, Ivan Velez Jr., who co-working with other writers and artists was responsible for Milestone's Blood Syndicate (1993-1996), which portrayed a multiethnic street gang of superheroes; second, Richard Dominguez, who in 1993 gave birth to El Gato Negro (published by Azteca Productions), which features Francisco Guerrero, a public defendant by day and a superhero at night, that is, a middle-class Chicano who tries to use both his superpowers and his college education to help his community. Dominguez also created Team Tejas (published by Azteca Productions in 1997), the story of another multiethnic superhero team which is led by yet one more middle-class Chicano, Jonathan Gonzalez, assistant mayor of Dallas. In opposition to the stereotypical Latino/a characters that abound in mainstream comics, Dominguez portrays heroes who belong to the middle class, not the street gang, and face serious psychological dilemmas.

\footnotetext{
${ }^{1}$ A comprehensive study of Latino/a characters in Marvel and DC Comics can be found in Aldama 2009: 31-44.

${ }^{2}$ A comprehensive study of Latino comic-book writers and artists can be found in Aldama 2009: 44-56.
} 


\section{LATINA SUPER-HEROINES IN MAINSTREAM COMICS: TOKENISM AND REINFORCEMENT OF NEGATIVE STEREOTYPES}

As I have already said, the first Latina super-heroine, Bonita Juarez (Firebird), appeared in 1981. Since then, mainstream companies have made an effort to introduce more and more ethnic female characters in their superhero comics, yet, as Aldama has put it, "the representations of Latinas are still few and far between" (2009: 56). In Marvel Comics Universe one may find Anya Sofia Corazon (Araña), a half Mexican, half Puerto Rican super-heroine (Araña. The Heart of the Spider, 2005), created by writer Fiona Avery and artist Mark Brooks. Puerto Rican Angela del Toro, White Tiger (White Tiger, 2007), devised by writer Tamora Pierce and artist Timothy Liebe, also lives in Marvel's Universe, as do Maria Vazquez (Tarantula), who debuted in the Heroes for Hire series following the Civil War series (2006-2007) and about whom virtually nothing is known, and Jacinta Rodriguez, a minor character, as she only appeared in one issue of Gail Simone's Agent $X$ series.

Anya Corazon is advertised on the book's back cover as Marvel's first Latina hero: "Sugar and spice and everything nice - that's what this little girl is totally NOT made of!" (2005, back cover). And, in fact, she is a brave and bold teenager who dares to fight against big boys even before discovering her superpowers. Her story may certainly help young women feel empowered because of that, but her Latinidad will not make her particularly appealing to Latinas, as it is reduced to a few insubstantial markers: she is dark haired and her skin is darker than that of average Anglo women; her parents call her "mi arañita," which is why she chooses "Araña" as her nickname. But other than that, there is hardly any clue in the story that allows readers to further connect her character with the Latino community. She lives in Fort Green Brooklyn, New York City, a racially mixed neighborhood, so on that too her Latinidad seems to be a mere accident that slightly colors her skin brown and determines her Spanish nickname.

For her part, Angela Del Toro, who is older than Anya Corazon, has been granted a more openly sexualized body, one that is more in keeping with that of the stereotypical Latina: dark haired too, but wearing much longer hair than Anya; Angela's skin is brown like Anya's, but her superhero costume makes her sexier, and the postures her body adopts more clearly emphasize her ample breasts and hips. Her facial gestures, too, are sometimes presented to provoke sexual arousal, as in a single full-page panel following a piece of news in the fictional newspaper Daily Bugle in which, interestingly enough, Angela touches one of her breasts - as she seems to be rubbing her amulet - and inclines her head backwards and sideways, thus making her breast protrude while her neck and right-hand cheek get struck by a beam of white light that makes her look very pale. Her lips, partly open, do the final trick. This is Angela in her sexiest pose, and, not accidently, in her whitest portrayal too.

As in the case of Anya Corazon, this Latina superhero may be attractive for heterosexual men (she seems designed to be so), but for Latina women in search of 
powerful Latina role models, Angela Del Toro has little to offer. Once again, her Latinidad is reduced to a few body marks that make her particularly "hot," a name that happens to be Spanish, and a number of mystical amulets that connect her with some supposedly Latino past. To make matters worse, in the newspaper already referred to there is an article devoted to her that further stresses her stereotypical nature:

Normally we at The Bugle don't like Costumes - but in your case, baby, we'll make an exception! This hard-fightin', gun-totin' hot tamale was seen beating the stuffing out of a bunch of gang punks near the Bronx Zoo - when she wasn't blinding them with her white skintight outfit that hugs her curves in all the right places.

The piece of news is accompanied by a black and white "picture" of Angela in superhero costume. The shot, taken from above, emphasizes Angela's ample breast, wide hips and full thighs. With this visual aid, the text's message becomes even clearer: Angela is a great super-heroine because she is really hot - her curves can dazzle the city's thugs just as her superpowers -; her Latinidad has no relevance whatsoever other than making her a sexy brown bimbo; last but not least, the fact that the journalist calls her "baby" and "hot tamale," thus metonymically presenting her as a Latino type of food, reduces her to a manageable and infantile creature, as well as an edible object, one that is there for someone else's enjoyment, one that can be easily discarded or substituted. That is why the journalist starts by saying that he does not like "Costumes," but he is ready to make an exception in the case of Angela and to spare her life, as she is nothing but a "baby" and a "hot tamale."

The Luna Brothers, for their part, are famous Philippine comic artists that have created a Latina super-heroine who has had great resonance among comic readers, as it has been published by Image Comics, one of the largest comic book publishers in North America. Ultra: Seven Days (2008) tells the story of three super-heroines: Pearl Penalosa (Ultra), a Latina, and her friends Jennifer Janus (a cowgirl and therefore representative of the Anglo-American woman) and Olivia (of Italian descent). Critic Hilary Goldstein (2005) has compared this comic book to the TV series Sex and the City, but "in tights." In fact, the three friends live in fictional Spring City, a place that resembles a US city of the Snow Belt, but also Los Angeles in the seventh issue (during the Annual Superhero Awards), and lead lives that could well be those of any celebrity, as they are followed by paparazzi and their bodies appear in giant billboards and in women's magazines advertising all kinds of products. Their glamorous lives are not exempt from pressures, both at work as superheroes who are constantly facing evil powers, and as women who have problematic relationships with their relatives or who fail to engage in successful relationships with men.

The authors seem to have attempted to introduce some political content in their work, as when they make Ultra state, in an interview, that she endures triple discrimination as a woman, a Latina and a Superhero: "Being a female, Hispanic 
Superhero - a triple minority-." Or when Ultra asks her boss to change her costume: "We gotta do something about this outfit. I know marketing is pushing for sex appeal, but the tube top just feels stupid in mid-January. Seriously... Any form of insulation around the general nipple-area would be highly appreciated." However, the political content is systematically whitewashed: comparing discrimination based on ethnicity with one's belonging to the minority group of superheroes trivializes the former; on the other hand, Ultra's realization that her body is being used by male chauvinists and her subsequent protest are finally disregarded - and similarly trivialized - by her boss's answer that her outfit might be revised, but "the tube top stays, sorry-fan polls are unanimous." Similarly, there is an attempt to bring in the questions of sexism and racism in a scene in which Ultra sees some vatos doing graffiti on a billboard where her image is used to advertise a cola drink. They've written the word "skank" (slang for "promiscuous") on the ad; on seeing her, one of them says: "You messed up. You went Gringo when you shoulda went Latino," and another one adds: "For real. You need to keep it Brown, Chica. We vatos know how to treat our bitches." This could have been a good opportunity to make Ultra react against their male chauvinism and their racism, but the scene is abruptly interrupted and Ultra is thus prevented from showing any reaction. Eventually, readers get the feeling that her most important problem has nothing to do with either sexism or racism, but with the circumstance that she has not found her true love yet, despite the fact that a fortune teller told her that she would find him in eight days' time. So, in this case, the protagonist's longing for romance crushes the possibility of her delving in other social and political issues that profoundly affect her life. She chooses not to concern herself with them, and instead abandons herself to the myth of romantic love. For her apolitical attitude she will finally be rewarded in the book's last scene, where she is given a new chance to engage with yet another guy. That is, after all, all she seems to be interested in.

\section{LATINA SUPER-HEROINES BY LATINO/A ARTISTS AND WRITERS: FIGHTING RACISM AND SEXISM}

Given the potential that a superwoman can have to help other women feel empowered, in the last few decades more and more Latino/a artists and writers have made use of super-heroines in their works. From the 1990s onwards, feminist criticism has tried to recover the few female superheroes that existed, analyzing their contribution to the feminist cause. Such is the case of studies such as Trina Robbins' The Great Women Superheroes (1996) or From Girls to Grrrls: A History of Women's Comics from Teens to Zines (1999), or also her book The Great Women Cartoonists (2001). More recent is Lillian S. Robinson's Wonder Women: Feminism and Superheroes (2004), as well as the documentary Wonder Women! The Untold Story of American Superheroines (2012). These works, however, focus primarily on 
white super-heroines: mostly on Wonder Woman, by far the best well-known of the super-heroines, but also, to a lesser degree, on Supergirl, Invisible Girl, Invisible Woman or She Hulk. What characterizes those studies is an ethnocentric focus that virtually crosses out ethnic super-heroines, who do exist, if in smaller numbers that male superheroes and white super-heroines.

Studies that seriously take ethnic super-heroines into account are quite recent. Among the works that focus on Latina super-heroines it is worth highlighting Frederick Luis Aldama's Your Brain on Latino Comics (2009), which devotes a brief section to Latina super-heroines, aptly entitled "Spandexed Latinas, Where Art Thou?" (2009: 56-59). Also, Laura E. Pérez's Chicana Art: The Politics of Spiritual and Aesthetic Altarities (2007), which dedicates a chapter to analyzing the works of Laura Molina and Isis Rodriguez, "On The Interface of the Pictographic: The Comic Book-Style Art of Isis Rodriguez and Laura Molina" (2007: 230-241). Deanna Shoemaker $(2005,2011)$, for her part, has studied Deborah K. Vasquez's comic strips, which feature Citlali and Citlalita, two super-heroines. Other critics have looked into the multiple representations of the Virgin of Guadalupe as a superhero (see, for example, Nicole Stratten 2009). My own analysis of Latina super-heroines is therefore influenced by all these other previous analyses.

\subsection{A CHICANA SUPER-HEROINE IN VERSE}

One of the first aspects I would like to point out is the fact that the super-heroine phenomenon is not restricted to the field of comics. Thus, novelist and poet Gloria Velásquez is the author of a poem entitled "Superwoman" that appeared within the poetry collection I Used to Be a Superwoman. Superwoman Chicana (1997). The book cover (by artist G. Bermúdez) offers the image of a multiple-armed Chicana that represents the poetic persona of the above-mentioned poem. ${ }^{3}$ With each of her hands she holds an object directly or indirectly referred to in the poem; they are all household utensils that speak of her household duties. Hanging from her shoulders there is a bag where she carries what looks like a journal of Psychology, the degree that she is taking classes of. Behind her, a giant " $\mathrm{S}$ " reminds us of the logos superheroes usually carry on their chests or somewhere else on their costumes. Here the superhero motif is clearly used with a feminist intention: this new type of Chicana woman, who has achieved middle-class status, in as much as she is living in an urban environment and is able to attend university classes, is nevertheless still oppressed by male chauvinism, which has forced her to take a "double burden" or, using Arlie Hochschild's expression, a "second shift" (1989); in other words, the superhero motif

\footnotetext{
${ }^{3}$ You may find poems and songs by G. Velásquez, including "Superwoman Chicana" (Track 27), here: http://www.cdbaby.com/cd/gvelasquez2.
} 
is employed to denounce a patriarchal system that allows women to have a career outside the home so long as they do not give up traditional gender roles.

\subsection{A CHICANA SUPER-HEROINE IN CHILDREN'S LITERATURE}

In their children's book Super Cilantro Girl / La Superniña del Cilantro (2003), writer Juan Felipe Herrera and illustrator Honorio Robledo Tapia have also taken up the super-heroine motif. Their aim in so doing is full of political intent, too. Their story seems an attempt to empower small Chicanas by helping them understand the plight of the grown-ups, some of whom are confronted with the difficulties of living in the USA without green cards or of having their families separated by the MexicoUS border. The writer himself, in an introduction to the book, acknowledges his debt to the experience of crossing the border, both his own crossing from the USA to Mexico as a child and his relatives' crossing from Mexico to the US. He also admits that he owes the conception of his story to the superhero movies he remembers seeing as a child during his stays in Mexico. Because of those influential factors, in his book a young girl, Esperanza Sinfronteras, magically becomes Super Cilantro Girl after holding a bunch of cilantro leaves and wishing she could help her mother - who has been stopped at the border in Tijuana - to enter the US as soon as possible. Once the transformation of the girl has taken place, she flies all the way to Tijuana, arrives at the "great gray building that keeps people in who want to move on" (22), "leaps over the wire mesh border wall, scales the patrol tower, and cranes her long neck" (23). On seeing her mother, she says: "I am Super Cilantro Girl. I am taking you back home to your daughter" (24), and then actually tucks her mum into her shirt pocket and flies over the border wall, followed by helicopters and patrol cars. To make things more difficult for the patrol officers, she even makes the border disappear under magically grown vines, trees and cilantro leaves that cover absolutely everything. The officers, amazed at what they see, halt their chase and exclaim, "iQué bonito!," as they have suddenly learnt to speak Spanish (26). At the end of the book, readers discover that the adventure has been nothing but a dream provoked by the uneasiness the girl experienced after learning that her mother had had to travel to Mexico. In any case, the book manages to help small Chicanas come closer to the complexities of living on the borderlands.

\subsection{CHICANA SUPER-HEROINES IN ART}

Comic style has also influenced artist Isis Rodriguez, who is responsible for a number of super-heroines. Her Wonder Woman LMA (acrylic on Bristol, 30x40 inches, 1999) and her Virgin LMA (acrylic, pen and ink on Bristol, 19x16 inches, 1999) are part of the Little Miss Attitude Series, ongoing since 1996, which has succeeded in "creating 
images of adventurous, self-possessed young women who can hold their own, providing empowering visual models for young women who feel the lack of options offered them in patriarchal culture where only guys seem to have the adventures" (Pérez 2007: 232). With her mischievous-looking virgins - her Virgin LMA is described as a "spunky cross between Supergirl and a "tween Virgin of Guadalupe" (Pérez 2007: 232) —, constant references to the apparently harmless landscape of animation and childish cartoons and, ironically, ubiquitous elements taken from a patriarchal erotics (hence the strippers that people this artist's works ${ }^{4}$ ), Rodriguez has been said to produce a harsh critique of female representation under patriarchal rules. It has also been pointed out that Rodriguez's super-heroines "do not cater to the simple, untroubled fantasies of the typical, adolescent Anglo American male comic book and cartoon audience" (Stratten 2009). To start with, they are dark-skinned. Besides, they are made to look as Latina women do in contemporary life - her Virgin LMA, for example, "wears large hoop earrings and a chain" (Stratten 2009). This makes sense, Stratten says, because classic superheroes are also ordinary people who are usually in a position of disenfranchisement when they are not acting as superheroes. Thus, if "the Virgin of Guadalupe can be imagined as having supernatural strength and power, but at the same time can look like the average Chicana then that means that every Chicana has the strength and power to make a difference, to stomp out patriarchy and fight against racism and classism" (Stratten 2009). ${ }^{5}$

Deborah Kuetzpalin Vasquez is another Chicana artist that has also produced some art works that feature a Chicana super-heroine: Citlali, la Chicana Super Hero. Among her works representing Citlali we may find these: Citlali: Fighting for Homeland Security (sharpie on posterboard, wood, 28x42 inches, 2006); Citlali: Who's the Illegal Alien Pilgrim? (Homage to Yolanda Lopez; sharpie on posterboard, wood, 28x22 inches, 2006); Fiesta: Let's Chingar La Raza Week (digital image, 22x34 inches, 2002), and Citlali: Mujeres Against Bigotry (digital image, 18×24 inches, 2006). ${ }^{6}$ As way of example of this artist's work, we may focus on the latter digital image. It looks like a single-panel cartoon in which Citlali occupies the right-

\footnotetext{
${ }^{4}$ Apart from the strippers in the LMA series, Isis Rodriguez has done the My Life as a Comic Stripper series (1997). She has also collaborated with Mexican artist Guillermo Gómez Peña in an installation performance at Somar Theater (1998). In it Rodriguez introduced "La Supreme Chicana," a vacant-eyed porn-theater pole dancer who has been described as a "feminist superheroine and defender of the rights of sex workers" (Gómez Peña 200: 45).

${ }^{5}$ It should be noted that Chicana artists have been reinterpreting the image of the Virgin of Guadalupe since the early 1970s (Stratten 2009). However, I will not refer here to any of those works, as my interest in this paper is to focus on Latina super-heroines. Isis Rodriguez's Virgin LMA (also see her Virgin Superhero (1999) from the Virgin of Guadalupe Series), however, in as much it combines elements that pertain to the Virgin of Guadalupe with others typically associated with comic super-heroines, does qualify to be included in my study.

${ }^{6}$ For an in-depth study of these and other art works that feature Deborah Vasquez's Citlali, see Shoemaker 2011.
} 
hand side. At the top of the image we can read: "Mujeres against bigotry," and at the bottom: "Por mi raza habla el espíritu." A bubble coming out of Citlali's head adds: "Brown women, stand strong against racist immigration laws." Citlali is presented as a fierce dark-skin guerrilla fighter, with a strong and muscular left arm, a revolutionary bandera across her chest, and a bandana over her forehead. Coming out of her breast is the indigenous virgin, Tonantzin, and a long vein that leads the spectator's vision to Citlali's right hand, which holds the superhero's red heart and the heart of La Raza. Her face, looking serious and defiant, shows her determination and her courage.

Vasquez created her super-heroine in 1998 as a "combination of indigenous women, their Chicana activist daughters, and the spirit of strong women more generally" (Vazquez in a personal interview cited by Shoemaker 2011: 6), and thus gave her an Aztec name that means "to reach for the starts" (Shoemaker 2011: 6). Citlali speaks in both English and Spanish, and sometimes uses Aztec words. Her body puts up a "macha femme performance" that relies "on an intensely muscular and active body, physical aggression, the use of expletives and demonstrations of rage, intense expressions of sadness, pleasure, and nostalgia, and very direct challenges to 'los gringos' in power and people in oppressed communities to embolden themselves and fight back" (Shoemaker 2011: 5).The fact that she wears red, green, and white helps us see her as representing "a resistant Mestiza identity within a colonized U.S. landscape" that "demythologizes Wonder Woman's iconic symbology of U.S. nationalism and freedom and foregrounds instead the immigrant, the indigenous, the woman of color, the female guerilla fighter, as a way of reimagining a fractured, unjust, and changing national identity" (Shoemaker 2011: 5). Morover, it has also been argued that apart from deconstructing a homogeneous national identity, Citlali disrupts mainstream definitions of masculinity and femininity: "Importantly, no super hero men ever come to save Citlali in a pinch, there are no super hero romances to recuperate her into a heterosexual narrative, and while Citlali is attractive, she is so on her own terms rather than being positioned/drawn as a sexual object" (Shoemaker 2011: 14). Citlali's superpowers are indeed diverse and outstanding, which probably explains why Vasquez has used the image of Citlali in comic strips too. I will therefore return to her in brief.

\subsection{CHICANA SUPER-HEROINES IN SINGLE-PANEL CARTOONS}

As we have seen, some of the art works in which Citlali has been represented actually look like single-panel cartoons. But whereas Vasquez's works have been presented in art exhibitions and installations, ${ }^{7}$ cartoons characteristically appear in periodical

\footnotetext{
${ }^{7}$ According to a footnote in Lucha Vista Magazine, Vasquez's Citlali has appeared "in over thirty-five exhibitions including several one-woman shows, both nationally and internationally" (Lucha Vista Magazine 2009. Available at <http://www.luchavista.com/feature4.html $>$ Access: 14/06/2013).
} 
publications or, more recently, on electronic mass media. Such is the case of another Chicana super-heroine, Lucha Dora, created by Ernesto Cuevas, Jr., an artist from Texas whose works are rooted in the experiences and struggles of immigrants in the U.S. The Lucha Dora cartoons have appeared in an online magazine, Lucha Vista Magazine, whose founders/editors are Ernesto Cuevas himself and Lori Rodriguez, a scholar-activist from San Antonio, Texas. In those single-panel cartoons where she can be seen, she is often accompanied by Campesino Man, who represents "the strength of laborers and immigrants to resist racism and classism" (Lucha Vista Magazine), whereas Lucha Dora, the Chicana roller derby guerrillera (she roller skates, hence her nickname), "resists colonialism and patriarchy through embodying a 'third space' identity as a feminine militant agent for social change" (Lucha Vista Magazine). Both are fighting against the monster of U.S. imperialism, best represented not simply by a serpent-like monster painted blue and red, but also by the symbol of industrialization and capitalism, i.e., the skyscraper.

\subsection{CHICANA SUPER-HEROINES IN COMIC STRIPS}

Apart from introducing Lucha Dora and her partner Campesino Man, Lucha Vista Magazine has also published a few comic strips that feature Citlali and Citlali's younger version: Citlalita, la Chicanita Super Hero. The Citlali comic strip "first appeared in newsprint in numerous 2002 issues of La Voz de Esperanza ("The Voice of Hope"), a progressive monthly publication from the Esperanza Peace and Justice Center in San Antonio, Texas," and a "Citlali comic book is said to be in progress" (Shoemarker 2011: 1-2). I have not had access to those comic strips, though, but to the strips that have appeared in Lucha Vista Magazine, whose copyright says "1998." In the comic strip dedicated to Citlali a narrating voice explains the super-heroine's mythic origins, her source of energy (a pantheon of Mexican indigenous goddesses), and her aim as a super-heroine (the challenging of local and global institutional oppression). But we also get to hear Citlali's own voice. Through it we obtain further information about the exact goddesses from whom she descends, and which specific powers she has inherited from each of them. She likewise wonders why speaking Spanish is often considered wrong, and vindicates her own code-switching. The images put emphasis on representing those powerful women she refers to, but there is one panel that portrays an urban artistic form, one which characteristic of Chicano barrios, i.e. the mural. This one in particular shows some Chicano men: one is repairing a car, while others are playing their guitars and singing. To the right of this panel, we see Citlali stating that she "grew up con una comprensión de las circunstancias under which [her] gente lived," and that's why she vowed "to help them if they couldn't help themselves." These words, combined with the mural, expose her knowledge of Chicanos/as' experience, an important part of which is related to the barrio. The latter is connected with negative aspects, as its 
displacement within the geography of the city, or its association with a life of hard work, but also with positive ones, such as the idea of community, enjoyment and artistic creativity.

The two comic strips published in Lucha Vista Magazine that feature Citlalita are different in nature. One of them focuses on healthy food, which basically involves "decolonizing" one's food, that is, renouncing fast food and going back to the diet followed in North, Central and South America by the Anahuaca people prior to European colonization, which was based on products such as maiz, napal, chile, beans, etc. By eating these products, Citlalita's mother says, women will become strong "guerrilleras" and Citlali herself adds that growing these products without pesticides will also help Mother Earth be healthier, thus highlighting the connection between the anti-imperialist ideology that moves Citlalita and her eco-feminism. The other strip focuses on the barrio and, more specifically, on one of the problems that the barrio has been typically associated with, i.e., drug consumption and drug dealing. Besides, Citlalita criticizes the authorities that deal with those problems in a wrong way, as they imprison drug addicts or dealers without considering the causes (such as discrimination, lack of opportunities, etc.) that lead Chicanos/as to those illegal practices. This inappropriate treatment of the problem thus perpetuates structural inequalities:

I grew up watching gente in my barrio doing drugs. My mami would say that our gente turned to drugs and drinking because it was hard to be treated as less than in a place that was once ours. Our gente feel they cannot make the money they see people make on TV, so they turn to easy money and false prestige. It's hard to obtain "the American Dream" on minimum wage. She would say that "our cities just deal with the symptoms and refuse to look at the problems."

Her speech does not lead to desperation, though, as she shouts, "One day things will be different!" and in the final panel she calls on "las Madres Indígenas" to give the Chicano community powers to defend their culture, consequently putting an optimistic and empowering note on her last words.

\subsection{CHICANA SUPER-HEROINES IN COMIC BOOKS}

It is in comic books that the full potential of a Latina super-heroine can be best exploited, as in them those characters can be given more complex psychologies than in the brief span of a single-panel comic or a comic strip; in books, their personal stories may be better developed, thus permitting readers a greater understanding of their motivations and goals; besides, a longer narrative may provide these superheroines with situations that allow them to show all their capabilities. I have been able to find four works that belong in this category: Steven Conrique-Ross's Chesty Sanchez (1995), Laura Molina's Cihualyaomiquiz. The Jaguar (1996), Richard 


\section{Dominguez's Team Tejas (1997), and Jaime Hernández's Ti-Girls Adventures (2008). ${ }^{8}$}

Perhaps with the exception of Team Tejas, the least feminist and least political of all the books, the others have a clear political agenda: Jaime Hernandez's Ti-Girls approaches the lack of ethnic super-heroines in mainstream comic books, the issue of the Spanish language and that of the representation of the female body; Steven Conrique-Ross's Chesty Sánchez deals with the questions of stereotypes, also with language and, most obviously, with American imperialism. For its part, Laura Molina's The Jaguar offers the most conspicuous feminist Chicana super-heroine, and she is equally concerned with bigotry and white supremacy.

Team Tejas is a group of superheroes who live in Dallas, Texas. Jonathan Gonzales (aka Lonestar), the assistant mayor of Dallas, is their leader. The other members of the team are: Abel Castillo (aka Calibre), a college student; his sister, Vanessa Castillo (aka Reata), a fashion designer, and Daniel Brightfeather (aka Plainsman), a Native American astronomer. Their adventures take place in diverse places (Bosnia, the USA, the Artic). In them, Reata, who has powers to teleport herself anywhere and other objects and people within 500-mile radius, participates just as any other male member, and her contribution to the team's success is of equal importance. However, there are a couple of features of her character that may disappoint female readers in search of a powerful and non-stereotypical heroine: first, the fact that she is very protective of her brother, or her "little bro," as she calls him when they have just come back from their mission in Bosnia and Abel is being ironic about Daniel's strange behavior; second, the fact that the professions of the team members follow traditional gender roles. Accordingly, the leader holds an important political post in the city of Dallas; we see him inside the Town Hall, an impressive building with a classical façade, working in his office, in whose walls hang his degrees and the medals he has received; besides, he's wearing a serious suit and his body adopts postures of a responsible bureaucrat. Abel, for his part, is a 20 year old college student who, in his normal life, is seen playing football; that is, he is associated with action and strength, two clear masculine features. Daniel is also linked to stereotypes; as a Cherokee, his character is connected with nature, whom he calls his mother, as is his own father. He is seen losing his temper, riding a bike to forget his problems; that is, running away from society and trying to reconnect to Mother Nature. At least, he is said to be an astronomer, which sounds like a serious profession. For her part, Vanessa is a victim of a stereotypical representation of females. We do see her working, as we see Jonathan, but she is wearing shorts and a fancy bra while lying on a deck chair and drinking a soda, with the lap top on her

\footnotetext{
${ }^{8}$ I would like to express my gratitude to Richard Dominguez, Steven Conrique-Ross, Laura Molina and Isis Rodriguez for personally sending me their works and for corresponding with me or even skyping with me; without their invaluable help, this section would not have seen the light.
} 
knees. Her dress code and working place seem to confirm that there is nothing serious about her profession, that of a fashion designer, as opposed to Jonathan's.

The relatively small potential that Vanessa has as an inspiring super-heroine may be due to her creators' lack of concern with women's issues: Chicano artist and writer Richard Dominguez, who seems to have had the original idea for the team; Texan artist Randy Saffle, and Michael Moore, an African-American who is half Brazilian, responsible for the text. The other Chicana super-heroines I have found happen to be much more subversive than Vanessa, and therefore have more potential as female empowering characters. The Ti-Girls, to start with, show great diversity. As Glen Weldon puts it, Jaime Hernandez peoples his comic book "with women of all sizes, shapes and ages." As opposed to many a Marvel and DC comic, where "women with bodies that defy all laws of anatomy and physics are drawn lasciviously even in repose," Hernandez's characters "radiate a clear-eyed, self-possessed, don't screwwith-me confidence" (Weldon 2012). Besides, his diverse bevy of super-heroines shows numerous instances of strongly-felt sorority, as they make up a "living, fully formed universe of superwomen whose network of relationships has weathered many years of shared history" (Weldon 2012).

Hernandez's book features not one but three different teams of super-heroines: The Fenomenons, who wear expensive outfits and handle only special cases; the Zolars, from Pasadena, whose members get booted when they turn 21, and the TiGirls, made up solely of rejects from other super teams, which is why it is in it that we find fat and old women, Chicanas, and heroines that often resort to Spanish. For instance, we find Boot Angel, who is blond and has long, straight hair, but is no longer in her twenties and has grown a bit fat. Rejected by the Zolars a long time ago, she now joins the Ti-Girls and works together with Xochitl/Espectra, the leader of the Ti-Girls, even though she is an old woman who works as a maid for Space Queen (another superwoman who belongs to a much more glamorous team). Espectra used to be a professional wrestler back in Mexico - she claims that all super heroes from Mexico "started out in the ring" (22), which is also true of Chesty Sanchez, ConriqueRoss's super-heroine - , and now that she lives in the USA, she cannot avoid moving in between the two cultures, and their two languages, which is why she keeps codeswitching and also why she has been nicknamed "Espectra": "I remain forever half a person, neither here nor there [...] como una espectra" (98). Two other members of the Ti-Girls are Golden Girl, a blond beauty that seems to have remained faithful to the aesthetics of the 1950s, and Rocky/Weeper, another beauty who refuses to present herself as she is and prefers, instead, to wear a mask of an old witch to strike terror on criminals - the idea of the mask comes to her from her great-great-grandmother, who wore it to battle the KKK after the Civil War (80). By the end of Part Two of Number 34, the once unglamorous Ti-Girls become attractive enough for Alarma, a superwoman of Russian descent who is part of the Fenomenons, to join the band of rejects with whom sorority and friendship are secured. Boot Angel herself, who at the beginning of the story had asked Alarma for acceptance into the Fenomenons — "Do 
you have room for a fat ethnic chick who wants to do her part in ridding the world of bigotry and bulimia?" (5) - supporting her petition by claiming that more and more super women teams were accepting ethnic members those days, seems later perfectly happy to share her lot with Electra and the rest of the Ti-Girls.

Another interesting aspect of the comic book is the fact that it is almost exclusively peopled by female characters and that the main conflict the Ti-Girls are faced with is also typically a woman's concern. The conflict they have to solve in $\mathrm{N}^{\mathrm{o}}$ 34 has to do with helping another super woman, Penny Century, recover her two daughters, whose loss has resulted in Penny's violent and irrational behavior. Thus the city these characters inhabit is close to being presented as a woman-only place, which is definitely a change with respect to many other comic books in which women have little or no role. But, in my view, the political clout of the story resides in its critique of the traditional representation of the female body in comic books, one which tends to be sexist and ethnocentric; there is also a bold defense of Spanish, and an unequivocal attempt to convince readers of the need to reject all kinds of discrimination. The narrative makes use of irony to work on stereotypes and do away with them, as when Electra is presented as a vulnerable Chicana maid who is supposedly unable to understand English, but later on is revealed as a super woman, the leader of a team of super-heroines, and perfectly capable of code-switching. Finally, the fact that the super powers of the Ti-Girls, their sorority and good intentions do not prevent them from failing in their mission, adds to their credibility and attractiveness, rather than the opposite, as for female readers their model may seem more easily attainable.

Chesty Sanchez is another super-heroine who has great potential for female empowerment. On the comic book cover, we see, "from a low-angle shot, an epically proportioned, gun-toting, muscled Chesty Sanchez, along with her mariachi-outfitwearing sidekick, Torpedo" (Aldama 2009: 89). Her real name is Maria Sanchez and she is 23 years old. She was born in a small village, near Cuernavaca, Mexico, where she was "taller and stronger than any man." As other super-heroines from Mexico, she started her career as a wrestler of lucha libre, but an unfair scandal forced her to abandon all combats, despite the fact that she had become "a role model for young girls" (and one could add: "and every man's fantasy"). After being unfairly accused of fighting dirty, she moved with her parents to Mexico City and bought them a store, where she has been working ever since then.

Chesty Sanchez is a stereotypical super-heroine as far as her body is concerned. Needless to say, her nickname emphasizes the one quality that is commonly used to reify women, that is, their bosom. However, the author uses ample irony in his story in scenes that have to do with body representation, as we will see. That, together with the fact that the plot allows Chesty Sanchez to play a leading role in catching the bad guys, prevents readers from seeing Chesty as simply a "man's fantasy," and encourages them to recognize her as being highly empowering for females, who may 
enjoy both her courage, intelligence and resilience, on the one hand, and her physical attractiveness on the other.

While she is living and working in Mexico City she is offered a job by the Company Frijoles del Oro, which used to be Mexican, but has now been bought by an American enterprise. Chesty Sanchez only speaks Spanish, but the company wants her nonetheless, as they are trying "to employ heroes to do good deeds in the company's name," so as to improve their competitiveness both sides of the MexicanAmerican border. Actually, the company places a lot of emphasis on her look, as well as on the physical appearance of the man they hire as her sidekick, Pedro Alvarez (aka Torpedo, as his farts as worse than bombs). The company develops their image, one which horrifies them ${ }^{9}$ because it is based on the stereotypical representation of Mexicans, the Mariachi outfit, but there is nothing they can do about it: that image is "familiar to Mexicans, and says 'Mexico' to Americans." It conveys the degree of "Mexican-ness" that the company wants to transmit. Torpedo, who speaks English with a strong accent (but only when he chooses to do so, which puzzles the company men), exclaims: "Jou theenk we wan' to look like the American super heroes?," thus underlining the fact that neither he nor his mate will be easily appropriated by the American company. They accept to work for that company because they need the job, and Chesty Sanchez sees it as an opportunity to improve her public image, but they won't compromise their true Mexican identity to look like a product Americans can find palatable enough.

Chesty Sanchez and Torpedo's first mission is to find out who is responsible for an epidemic caused by food poisoning that is already causing havoc among the Mexican population. Soon they discover that the bad guy they have to fight against is an American called Marshall Weston, a veteran soldier that took part in the Desert Storm operation during the Gulf War (1990-1991). When he left the American army, he stole weapons from it and resold them in Latin America; then he set up in Mexico City ("an excellent source of good-low-cost labor," in his own words), improved upon a virus that had been developed by the Iraqis, and distributed it throughout Mexico City. Both Chesty and Torpedo will manage to dismantle his laboratory, to free his captives, and finally kill him, after which they move on to their next mission, which, comically enough, turns out to be the rescue of Enrique Iglesias!

Despite the humor and the irony of this comic book, it is undeniable that is deals with very serious issues. The story offers a harsh critique of American imperialism, which is shown to work here on two levels: first, on the level of the food industry through the reference to American food corporations that absorb smaller enterprises in poorer or developing countries, reducing the economic self-reliance of those countries - Mexico, in this case - as well as biodiversity, since they tend to

\footnotetext{
${ }^{9}$ The three Mexican characters that are shown the Mariachi-based superhero outfit exclaim in total shock: "Holy Mary, Mother of God," and the typography highlights their stupor: bold letters whose size progressively increases, and finally two exclamation marks
} 
introduce genetically-modified seeds whose patents they possess, and to eradicate all other seeds; second, on the level of the military through the reference to that veteran soldier that uses his experience in conventional and biological weapons to make money for himself. Both spheres, that of food corporations and the military, exploit Mexico as a source of cheap labor, and profit immorally, if legally in the case of food corporations, from a population, that of Mexicans, whom they take for clowns (let us remember the case of Chesty Sanchez and Torpedo being forced to represent "Mexicanness" by means of their costumes), for illiterates (hence the company's surprise at realizing Torpedo does speak English), or for servants (Marshall's captives working non-stop in his laboratory).

Though it is true that neither Chesty nor Torpedo can put an end to American imperialism in its entirety, it is no less certain that both play a significant role in curtailing its worst effects by erasing Marshall Weston from Mexico City and by securing the Frijoles del Oro Company needs to hire Mexican people (the former Mexican owner of the company, Mr. Diaz, Chesty Sanchez and Torpedo) for it to continue its activity. In other words, dismantling American imperialism proves an impossible task, but there are appropriation strategies that a super woman and her sidekick can use to contest its supposedly unlimited power. The fact that Torpedo videotapes Chesty's outstanding performance is one such strategy, as that implies that they have the right to self-representation, if not to choosing their outfit. In short, both characters manage not to play a totally submissive role, not to be treated as a subaltern, but as subjects whose entanglement with the imperialist forces is complex and nuanced.

Like Chesty Sanchez, Laura Molina's Linda Rivera, aka Cihualyaomiquiz, The Jaguar, is physically modeled on the hyper-sexualized super-heroine of the comic book tradition. However, there are several features that draw her apart from that same tradition. First, we can take into consideration the fact that she bears a Nahuatl name (which, according to a footnote means "woman ready to die in battle"). This name connects her with her ancestors' tradition, as does the fact that she invokes Huitzilopochtli, God of War, to obtain her super powers, and performs a ritual that involves lighting copal. She is not stuck in the past, though. She lives on the Eastside of Los Angeles, an area mostly populated by Chicanos/as, and, like many women her age, she has a career; in particular, she is "a scholar of the law." Her ethnicity, her being "situated" among a Latino community, and her middle-class background conform a second reason why Linda Rivera is not a conventional super-heroine. Thirdly, she is a highly politicized woman, profoundly concerned with the racist and sexist practices she perceives in California at the turn of the $20^{\text {th }}$ century. A caption on the cover, for instance, unambiguously presents her ideology: "Out of the heart of Aztlan into the New Age, comes a woman warrior dedicated to the struggle for social justice, human rights, and mother earth." The emphasis is not only on her goals, but on her Chicana identity, as she comes "out of the heart of Aztlan." Her political views are further pinpointed by the speech balloons where her actual words are given: Her 


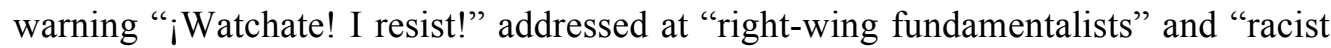
bigots and white supremacists," stresses that she is no "sissy" and will stop at nothing to pursue her goals. Finally, the lack of embarrassment in the use of the term "feminism" in another caption at the bottom of the cover, which is actually presented as a promising treat for readers who continue reading the rest of the comic book, further confirms her political commitment.

In this particular issue, Linda Rivera is concerned with Proposition 187, a law passed in California in 1994 that attempted to prohibit illegal aliens from using health care, public education and other services in that state. This law was very controversial. Opponents thought it discriminated against immigrants, especially of Hispanic and Asian origin, whereas supporters insisted that they were preoccupied about economic issues, as the state should not be expected to provide social services to so many illegal residents. The law was challenged by several lawsuits and found unconstitutional; Governor Pete Wilson, a Republican, appealed against the ruling of unconstitutionality, but in 1999 Democratic Governor Gray Davis withdrew the appeal, thus killing the law.

Laura Molina's comic book begins precisely with the reelection of Governor Wilson and the passing of Proposition 187. It then moves on to explain the consequences of that law: "A rightwing backlash brings a new attack upon civil rights, equal employment, and affirmative action," "Regressive legislation turns California into a police state," "Racist hate groups fester, proliferate and grow more vocal and violent," "Violence against La Raza and others increase - racism reaches intolerable levels." The strips show us the State Capital in Sacramento, where the Proposition has been passed; the streets of LA, where the police intimidate or beat immigrants, and the members of neo-Nazi groups prepare their assaults. The city of LA and the whole state are threatened by this piece of legislation. Meanwhile, Linda Rivera is working at home, preparing a case, but needs to get into a law office to check some papers. On her way out of that office, in the middle of the night, she is assaulted by a couple of neo-Nazis, but she fights back and leaves them both lying on the floor. In the two final panels, she ironically comments: "You guys are pretty lucky tonight anyway. After all... my ancestors used to eat their enemies." And then adds: "Viva La Raza!"

It is for that reason that we may agree with Laura Pérez that The Jaguar "battles neo-Nazi racism with Chicana/o pride, ironically bracing the frightening image of the bloody Aztecs in the Western imagination" (Pérez 2007: 241). Similarly, we may share Pérez's conclusion that "The Jaguar [...] overturns stereotypes of the Latina as passive, subservient, and, for that matter, less intellectually and culturally sophisticated with respect to idealized middle-class Euroamerican norms," and that Laura Molina "draws from a Mesoamerican cultural past and a present identification with the Indigenous in constructing her fearsome heroine, and this in itself is a tactic in the larger ongoing struggle against a racism that, like an evil comic book nemesis, 
keeps rearing its ugly head in ever-new twists of the same old plot" (Pérez 2007: 241).

\section{LATINA SUPER-HEROINES: GIRL POWER VS. FEMINIST EMPOWERMENT}

It has been often debated that women lack positive representations in mass media, in general, and in the comic world in particular, and that the scant presence of superheroines is a problem that should be readily solved. In Gloria Steinem's words: "Girls actually need superheroines much more than boys when you come right down to it because $90 \%$ of violence in the world is against females. Certainly women need protectors even more, and what's revolutionary, of course, is to have a female protector not a male protector" (cited in Rodriguez 2013). Shelley Armitage, to cite but another author who similarly points out the underrepresentation of strong female characters in the comic world, has expressed her views in these terms: "I asked of the comics what I later asked of Jung's female archetypes: where were the dynamic, strong, athletic, imaginative, problem-solving women who would not be rejected by society or men for being so?" (Armitage 2005: 155). Amanda Rodriguez, for her part, in a review of the already mentioned documentary Wonder Women! The Untold Story of American Superheroines (Dir. Kristy Guevera-Flanagan, 2012), mainly focused on the character of Wonder Woman, states that women's need for super-heroines in mass media has led them to give Wonder Woman and other super-heroines more relevance than they should have: "sometimes these heroines are not imbued with the most feminist qualities, but their success is a testament to that hunger for strong female representations" (Rodriguez 2013). These super women, she continues, are "independent, smart, capable, and confident" and they "do show the women watching them that they, too, can be all those things" (Rodriguez 2013).

The Latina super-heroines I have analyzed in this paper, even when they fail to be flawless, thus perform a fundamental role, because their existence palliates to some extent the lack of female strong characters in popular culture, a lack that is even more poignant in the case of ethnic female characters. As we have seen in the last section, Latino/a writers and artists, with few exceptions, have given shape to super women with brains (as well as hypersexy bodies, in some cases), but always engaged in a battle against the forces of sexism, racism, American imperialism, and lack of representation in a world, that of comics, that is traditionally a projection of Eurocentric and heterosexual males. They defy those projections by bringing their largely untold stories into the comic realm, thus showing "their refusal to compromise what they want to say and draw [...] and, finally, their criticism of mainstream cultures" (Pérez 2007: 240).

Moreover, they do so without renouncing the basic tenets of feminism and other subversive ideologies, as opposed to the non-Latino artists, who seem more clearly 
influenced by a Post-Feminist ideology that presents itself in the form of Girl Power. Following Mary D. Vavrus (2002), Post-feminism has been defined as an ideology that rejects First and Second Wave's more provocative challenges, as for example those that are grounded in a critique of capitalism and class privilege, as well as the concepts of patriarchy and collective action. In fact, it can be considered as a lifestyle, rather than as an activist movement, given the fact that its main aim is the achievement of a higher-status lifestyle that allows consumption of high-status commodities (Hains 2009: 99). Girl Power, in its turn, has been presented as being a variety of Post-Feminism tailored for girls, just as Power Feminism would be a form of Post-Feminism that can be more appealing for older women (Hains 2009: 99). Girl Power has also been explained as a kind of female empowerment that is restricted "to patriarchal constructs of what it means to be feminine" (Newsom 2004: 2). In that sense, the primary restriction would be the body type. Thus, while women are allowed to be active, aggressive and self-sufficient, Girl Power forces them to maintain a strongly feminine appearance. Within that logic of Girl Power, one may find that the super-heroines created by non-Latino artists make normative femininity mandatory and therefore they exclude girls or women who do not successfully perform normative femininity. Accodingly, Ultra Penalosa, Araña or White Tiger are devoid of any political commitment. Their message is watered down. The fact that they are Latina super-heroines is noteworthy, but it is nevertheless too obvious that they fail to threaten the status quo. White Tiger, for example, shows an over-stated feminine body that offers pleasure to a heteronormative gaze. For her part, Ultra falls prey to the lure of capitalism, as she herself offers her body to prompt others to acquire high-status commodities. Nevertheless, their role models may be appealing for a given feminine audience, as they transmit some interesting pieces of news: that women are powerful, not victims, that being a female is fun, and that equality has been fully achieved, what makes feminism and other subversive discourses redundant.

On the contrary, the super-heroines created by Latino artists convey messages are deeply connected with a number of political struggles, and they unabashedly aim at subverting the status quo. The Ti Girls, for example, boast bodies that fail to conform to hyper-feminine qualities: some bodies are fat, others are old; others, yet, refuse to be complacent with the heteronormative gaze, as they are lesbian. The critique of capitalism and class privilege is obvious in several other cases, as in the comic strips of Citlali and Citlalita, or in the one-panel cartoons of Lucha Dora, who joins Campesino Man to fight the forces of Empire. The issue of race, of being brown women of La Raza, is overtly stated in many cases too, but even more conspicuous in the character of The Jaguar, who repeats the mottos chanted by the members of the Chicano Movement in the 1960s. Their cultural right to speak Spanish or to codeswitch between Spanish and English whenever it suits them best is also explicitly defended by several super-heroines, as is their right to belong in two or more cultures or to live on the borderlands, like Espectra from the Ti-Girls. The Post-Feminist 
belief that equality has been achieved and the ghost of feminism no longer needs to be called for is rejected by Gloria Velazques's Superwoman just as much as by Laura Molina's The Jaguar, who in the book's front cover entices readers to find "More Feminist-Chicana Anarchy" inside the book. Last but not least, Latino/a artists' critique of Eurocentrism and Western Imperialism is nothing but evident in several characters, as shown in the costumes that some super-heroines wear, reminiscent of Latino cultures (as for example that of the Super Cilantro Girl, dressed in green as the leaves of cilantro, a spice commonly used in Latino cuisines), in the evil forces they fight against, as is the case of Chesty Sanchez, or in their Nahuatl names. While the "hot tamales in tights" created by non-Latino/a artists continue reinforcing stereotypes, these other women warriors, wrestlers, guerrilla fighters and militant agents for social change watch over America making sure that Latina women's cultural and civil rights are respected. At least in the universe of comics.

\section{REFERENCES}

Aldama, Frederick Luis (2009). Your Brain On Latino Comics. From Gus Arriola to Los Bros Hernandez. Austin: The University of Texas Press.

Armitage, Shelley (2005). Wonder Women: Feminisms and Superheroes by Lilliam S. Robinson. Tulsa Studies in Women's Literature 24.1: 155-157.

Avery, Fiona (2005). Araña. The Heart of the Spider. New York: Marvel.

Brown, Jeffrey A. (2011). Dangerous Curves. Action Heroines, Gender, Fetishism, and Popular Culture. Jackson, MS: University Press of Mississippi.

Dominguez, Richard (1993). El Gato Negro No. 1. San Antonio, TX: Azteca Productions.

Dominguez, Richard (1997). Team Tejas No. 1. San Antonio, TX: Azteca Productions.

Goldstein, Hilary (2005). [A Review of] Ultra: Seven Days: Sex and the City Goes Superheroine in One of The Best Flight-And-Tight Books of the Past Five Years. http://www.ign.com/articles/2005/04/26/ultra-seven-days-review. Accessed 03/07/ 2013.

Gómez Peña, Guillermo (2000). Dangerous Borders Crossers. The Artists Talk Back. London: Routledge.

Gregory, Roberta (1987). Winging It. A Graphic Novel for the Nineties. Part 1 of 2. Van Nuys, CA: Solo Productions.

Guevara-Flanagan, Kristy (2012). Wonder Women! The Untold Story of American Superheroines. Vaquera Productions LLC.

Hains, Rebecca C. (2009). Power Feminism, Mediated: Girl Power and the Commercial Politics of Change. Women's Studies in Communication 32.1: 89113. 
Hernandez Brothers, The (2008). Love and Rockets $N^{o}$ 1. Seattle, WA: Fantagraphics Books.

Hernandez, Jaime (2008). Ti-Girls Adventures No 34. Part One: The Search for Penny Century. In Hernandez Brothers, The, 1-25.

Hernandez, Jaime (2008). Ti-Girls Adventures No 34. Part Two: Penny Is Found. In Hernandez Brothers, The, 76-100.

Herrera, Juan Felipe (2003). Super Cilantro Girl. La Superniña del Cilantro. Illustrations: Honorio Robledo Tapia. San Francisco, CA: Children's Book Press.

Hochschild, Arlie Russell (with Anne Machung) (1989). The Second Shift: Working Parents and the Revolution at Home. New York: Viking Penguin.

Innes, Sherrie A., ed. (2004). Action Chicks: New Images of Tough Women in Popular Culture. New York: Palgrave Macmillan.

Luna Brothers, The (2004, 2008). Ultra: Seen Days. Berkeley, CS: Image Comics.

Molina, Laura (1996). Cihualyaomiquiz, The Jaguar. Self published.

Newsom, Victoria A. (2004). Young Females as Super Heroes: Superheroines in the Animated Sailor Moon. Femspec 5.2 ("Girl Power" issue): 57-81.

Pérez, Laura E. (2007). Chicana Art: The Politics of Spiritual and Easthetic Altarities. Durham and London: Duke University Press.

Pierce, Tamora \& Timothy Liebe (2007). White Tiger: A Hero's Compulsion. New York: Marvel.

Robbins, Trina (1996). The Great Women Superheroes. Amherst, Mass.: Kitchen Sink Press.

Robbins, Trina (1999). From Girls to Grrrls: A History of Women's Comics from Teens to Zines. San Francisco: Chronicle.

Robbins, Trina (2001). The Great Women Cartoonists. New York: Watson-Guptill.

Robinson, Lillian S. (2004). Wonder Women: Feminism and Superheroes. New York: Routledge.

Rodriguez, Amanda (2013). Wonder Women and Why We Need Superheroines. http://www.btchflcks.com/2013/05/wonder-women-and-why-we-needsuperheroines.html\#.Uz0ajXnNt9A. Accessed 03/03/2014.

Rodriguez, Lori \& Ernesto Cuevas, Jr. ed. LuchaVista Magazine. Campesino Man y Lucha Dora. http://www.luchavista.com.

Romero-Jódar, Andrés (2013). Comic Books and Graphic Novels in their Generic Context: Toward a Definition and Classification of Narrative Iconical Texts. Atlantis 35.1: 117-135.

Ross, Steve (1995). Chesty Sanchez No. 1. San Antonio, TX: Antactic Press.

Ross, Steve (1996). Chesty Sanchez No. 2. San Antonio, TX: Antactic Press.

Ross, Steve (1999). Chesty Sanchez. 96 Page Super Special. San Antonio, TX: Antactic Press.

Ross, Steve: The Origin of Loca Sanchez. http://mrstevesstorytime.blogspot.com.es/ 2007/09/origin-of-loca-sanchez-chesty-sanchez.html. Accessed 4/12/2013. 
Shoemaker, Deanna (2005). Cartoon Transgressions: Citlali, La Chicana Superhero Avenges Neo-Colonialism. Blackstream: 105-118.

Shoemaker, Deanna (2011). Cartoon Transgressions: Citlali, La Chicana Super Hero as Community Activist. Liminalities: A Journal of Performative Studies 7.1. http://liminalities.net/7-1/citali.pdf. Accessed 13/06/2013.

Stratten, Nicole (2009). The Virgin of Guadalupe: an Image of a Superhero for Chicana Artists. http://kookitasthoughts.blogspot.com.es/p/virgin-of-guadalupe. html. Accessed 9/07/2013.

Vasquez, Deborah Kuetzpalin (1998). Citlalita. La Chicanita Super Hero. Comic strip.

Vasquez, Deborah Kuetzpalin (2002). Fiesta: Let's Chingar La Raza Week. Digital image.

Vasquez, Deborah Kuetzpalin (2006). Citlali: Fighting for Homeland Security. Sharpie on posterboard.

Vasquez, Deborah Kuetzpalin (2006). Citlali: Mujeres Against Bigotry. Digital image.

Vasquez, Deborah Kuetzpalin (2006). Citlali: Who's the Illegal Alien Pilgrim? (Homage to Yolanda Lopez). Sharpie on posterboard.

Vasquez, Deborah Kuetzpalin (2009). Citali. La Chicana Super Hero. LuchaVista Magazine. Comic strip. http://www.luchavista.com/feature4.html.

Velásquez, Gloria L. (1997). I Used to Be a Superwoman. Superwoman Chicana. Illustration: G. Bermúdez. Houston, TX: Arte Público Press.

Vavrus, Mary D. (2002). Postfeminism News: Political Women in Media Culture. Albany: SUNY Press.

Weldon, Glen (2012). Jaime Hernandez Bridges The Indie-Vs.-Cape Divide. http://www.npr.org/2012/08/02/157301000/jaime-hernandez-bridges-the-indie-vscape-divide. Accessed 04/12/2013. 